\title{
Use of indigenous herbal medicine- purple lady/iron leaf (Telanthera ficoidea) as a natural dye source for dyeing of mulberry silk fabric
}

\author{
POMIMA DUARAH AND SATVINDER KAUR
}

Received: 27.02.2014; Revised: 19.09.2014; Accepted: 30.09 .2014

See end of the paper for authors' affiliations

\section{POMIMA DUARAH}

Department of Textiles and Apparel Designing, College of Home Science, Assam Agriculture University, JORHAT (ASSAM) INDIA

Email : pomimaduarah@ rediffmail.com
ABSTRACT : Naturally occurring materials are non-toxic, biodegradable and non-carcinogenic. Environmental considerations are now becoming an additional important factor during the selection of consumer goods including textiles all over the world. So, interest in natural product is gaining importance throughout the world and people are becoming aware of the need for eco-friendly materials. For the research, mulberry silk fabric was dyed with purple lady (Telanthera ficoidea) and mordant selected were alum and tea. All the three mordanting method viz., pre, simultaneous and post mordanting method were used. The dye materials were collected and extracted from the leaves and stems of purple lady with method. The silk fabric samples were degummed, ironed and dyed. The O.D. value before and after dyeing were recorded. Purple lady (Telanthera ficoidea) natural dye could be used effectively for colouring of mulberry silk fabric.

KEY WORDS: Mulberry silk, Purple lady, Telanthera ficoidea, Fastness, Properties

— HOW TO CITE THIS PAPER : Duarah, Pomima and Kaur, Satvinder (2014). Use of indigenous herbal medicine- purple lady/iron leaf (Telanthera ficoidea) as a natural dye source for dyeing of mulberry silk fabric. Asian J. Home Sci., 9 (2) : 409-412. 